\title{
WACANA ROMANTISME DALAM SEJARAH SASTRA INDONESIA PERIODE KOLONIAL BELANDA (1900-1942)
}

\author{
Dwi Susanto*, Rianna Wati \\ Pendidikan Bahasa dan Sastra Indonesia, Fakultas Keguruan dan Ilmu Pendidiakan, Universitas Sebelas Maret, \\ Indonesia \\ *Corresponding author: dwisastra81@gmail.com
}

\section{INFORMASI ARTIKEL}

\section{Sejarah Artikel}

Diterima: $11 / 8 / 2018$

Direvisi: 31/5/2019

Disetujui: 2/6/2019

Tersedia Daring: 9/6/2019

\section{Kata Kunci:}

Estetika Romantisme

Sastra Indonesia

Kuasa

\section{ABSTRAK}

Sejarah sastra Indonesia didominasi oleh wacana estetik romantik atau materialisme. Hal ini memengaruhi cara pandang terhadap kesastaraan Indonesia. Tulisan ini bertujuan untuk melihat pembentukan dan persebaran wacana estetika romantik dalam sejarah sastra Indonesia. Teori yang digunakan adalah wacana dan kuasa dari Foucault. Objek kajian yang digunakan adalah wacana dan kuasa dalam sejarah sastra Indonesia, terutama wacana estetika romantisme. Hasil yang diperoleh adalah bahwa wacana estetika romantisme dan sejarah sastra Indonesia dibentuk dan digunakan oleh kuasa kolonialisme Belanda. Hal ini ditujukan untuk membentuk masyarakat terjajah sesuai citra dirinya. Sebagai akibatnya, wacana estetika yang lain disingkirkan dan dianggap bukan sebagai kesastaraan sehingga tidak masuk dalam sejarah sastra. Hal ini berlanjut hingga pada masa sesudahnya dan Orde Baru yang menggunakan cara dan strategi yang serupa dengan periode kolonial.

\section{ABSTRACT}

Keywords:

Romanticism Aesthetics

Indonesia Literature

Power
The history of Indonesian literature is dominated by romantic aesthetic discourse or materialism. This affects the perspective on Indonesian literacy. This paper aims to look at the formation and distribution of romantic aesthetic discourses in the history of Indonesian literature. The theory used in this research is Foucault's theory of discourse and power. The object of the study is discourse and power in the history of Indonesian literature, especially the discourse of romantic aesthetics. The results of the research reveal that the aesthetic discourse of romanticism and the history of Indonesian literature is formed and used by the power of Dutch colonialism. It is intended to form colonized communities according to their image. Consequently, other aesthetic discourses are removed and considered not as literary work so that they are not included in the Indonesian history of literature. This condition continues until the later period and the New Order, in which the authority carry on methods and strategies similar to that of the colonial period.

Copyright@2019, Dwi Susanto, Rianna Wa This is an open access article under the CC-BY-3.0 license
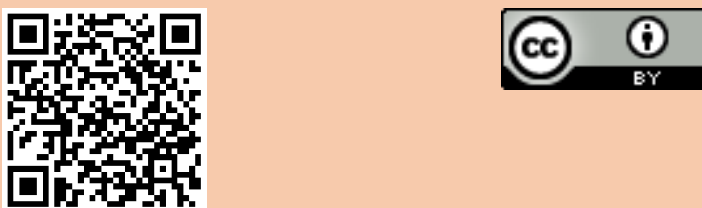


\section{PENDAHULUAN}

Buku sejarah sastra Indonesia memiliki kecenderungan yang memulai kelahiran kesastraan Indonesia "modern" dengan ditandai terbitan karya sastra dari Balai Pustaka. Hal ini terlihat dari buku yang ditulis oleh A Teuuw (Pokok dan Tokoh dalam Kesastraan Indonesia Baru I, 1959 dan Sastra Indonesia Modern I, 1980), Jakob Soemardjo (Lintasan Sastra Indonesia Modern I, 1992), Ajip Rosidi (Angkatan dan Periodisasi Sedjarah Sastra Indonesia, 1970), Bakri Siregar (Sejarah Sastra Indonesia Modern, 1964), dan lain-lain. Buku-buku tersebut mengedepankan beberapa hal, pertama, kelahiran sastra Indonesia modern didasarkan pada tradisi Balai Pustaka. Kedua, penulisan sejarah sastra didasarkan pada perkembangan bentuk karya, topik, dan pengarang. Ketiga, sejarah sastra Indonesia umumnya didasarkan pada periodisasi dari lembaga kesastraan dan generasi pengarang. Keempat, sejarah sastra Indonesia mengesampingkan "ekspresi" kesastraan yang berbeda dengan narasi yang "dibangun". Kelima, sebagai konsekuensinya, penulisan sejarah kesastraan Indonesia mengedepankan narasi estetika tertentu dengan menghilangkan estetika yang lain dan cenderung bias kolonialisme.

Berbagai fakta itu merujuk pada sebuah hipotesis bahwa sejarah sastra Indonesia bias kolonialisme sebab estetika yang dibangun adalah estetika romantisme, yang dikenalkan oleh kolonialisme Belanda. Hipotesis tersebut dibuktikan oleh penelitian dari Faruk (2002) mengenai tradisi kesastraan Balai Pustaka. Penelitian itu menyebutkan bahwa romantisme Eropa dijadikan ideologi. Bahkan, estetika ini (materialisme) menjadi landasan cara pandang terhadap kesastraan seperti humanisme universal (Sarwoto, 2018). Kesimpulan ini dapat dibuktikan melalui penelitian dan gagasan yang berkembang pada "masa kelahiran" hingga masa berikutnya. Sebagai contoh adalah kritik sastra yang berkembang dalam tradisi kesastraan Indonesia, seperti karya Ivan Adilla (A.A. Navis; Karya dan Duniannya, 2003), H.B. Jassin (Pudjangga Baru Prosa dan Puisi, 1961), Bakdi Soemanto (Sapardi Djoko Damono; Karya dan Dunianya, 2006) dan lain-lain. Dalam karya sastra, gagasan itu terlihat dalam Pujangga Baru hingga masa Chairil Anwar.

Sementara itu, penelitian terhadap sejarah sastra Indonesia telah dilakukan diantaranya oleh (Sykorsky, 1980), yang memberikan uraian tentang kelahiran genre sastra Indonesia melalui bentuk asli karya sastra (cerita pernyaian dan detektif). Semenatra itu, Salmon (1981) memberikan perhatian pada sastra peranakan Tionghoa, yang tidak pernah dibicarakan dan cenderung dianggap bukan "bagian dari sejarah sastra Indonesia". Di dalam penelitian yang lain, Salmon (1994) mengemukan tentang gagasan kelahiran roman modern dalam sastra Indonesia dengan mengacu pada karya sastra peranakan Tionghoa, Bintang Toedjoeh karya Lie Kim Hok. Jones (2013) memberikan catatan mengenai sejarah sastra Indonesia dengan memasukkan sastra peranakan Tionghoa sebagai korpus sastra Indonesia di masa kolonial. (Faruk, 2002) menentukan estetika yang dominan pada masa kolonial, yakni romantisme dengan kasus sastra tradisi Balai Pustaka dalam konteks sosial dan romantisme sebagai ideologi. Sementara itu, Susanto (2017) mengemukan tentang gagasan bahwa sastra peranakan Tionghoa Indonesia adalah bagian dari sejarah sastra dan penulisan sejarah sastra Indonesia harus mundur sejak 1890-an. Sementara itu, ada satu buku yang berusaha mencari jejak-jejak romantisme dalam teks sastra Indonesia, yakni Membaca Romantisme Indonesia (Sapardi Djoko Damono ed., 2005), yang berisi kumpulan tulisan dari para kritikus sastra.

Satu penelitian yang signifikan dalam topik ini telah dilakukan oleh Jones (2013). Penelitian ini mengemukan tentang kebijakan budaya selama abad ke-20 di Indonesia. Kebijakan tersebut menurutnya dipengaruhi wacana dan kuasa, seperti bias kolonialisme hingga kekuasaan Orde Baru yang mendukung gagasan humanisme ataupun liberalisme. Kesastraan di era kolonial juga tidak terlepas dari kuasa kolonialisme dengan menghadirkan kesastraan kanon atau Balai Pustaka. Hal ini sesuai dengan topik penelitian ini yang 
menghadirkan wacana romantisme sebagai semangat atau estetika yang dominan di masa kolonial dan berbagai dampaknya.

Berbagai penelitian itu belum mengemukan wacana estetika yang berkembang dalam penulisan sejarah sastra Indonesia. Sebab, wacana estetika itu sendiri yang membangun konstruksi penulisan sejarah sastra dan berimplikasi "konsep estetik" sastra Indonesia. Beberapa kajian tersebut menimbulkan berbagai implikasi terhadap konsep estetika dan penulisan sejarah sastra. Pertama, penelitian tersebut tidak menunjukkan polarisasi estetik yang berkembang pada masa kolonial dalam sejarah sastra sebagai dasar bagi arah sejarah dan kritik kesastraan. Kedua, penelitian tersebut menghilangkan konteks historitas kelahiran sastra Indonesia dari sisi kemunculan estetikanya. Ketiga, keterputusan wacana estetika dalam sejarah sastra menjadi landasan utama, sehingga menegasi wacana dan konsep estetika yang lain. Keempat, tulisan tersebut hanya melihat bentuk formal dan genre kesastraan, tetapi tulisan itu tidak melihat esensi atau ruh estetika yang melatari genre dan bentuk. Sesunguhnya, hal itu menjadi bagian dari berbagai wacana yang berkembang. Kelima, selain itu, penelitian tersebut cenderung menghilangkan konteks sosial atas kelahiran kesastraan pada masa itu. Keenam, tulisan tersebut menolak kontruksi kuasa dan politis atas wacana estetika sejarah sastra Indonesia masa kolonial sebab bias kekuasaan tertentu.

Berbagai alasan itu menunjukkan bahwa wacana estetika terhadap kelahiran kesastraan Indonesia dan masa sesudahnya memiliki berbagai ketimpangan dan usaha penyingkiran atas keragaman estetika yang ada. Selain itu, fakta tersebut memberikan sebuah hipotesis bahwa ada usaha yang terpusat atau dominan dalam membentuk satu wacana dan konsep estetika yang tunggal. Hal itu tentu saja merupakan sebuah upaya politis dan ideologis untuk memberikan kekuasaan tertentu pada "satu kuasa" agar mendominasi dan mengatur segala fenomena dan wacana yang lain pada perkembangan berikutnya. Berbagai usaha penyingkiran dan penguatan satu kuasa itu memberikan praktik politis dan ideologis dalam sejarah sastra Indonesia dan kritik sastra. Oleh sebab itu, usaha penyingkiran dan penguatan sebuah wacana perlu dilihat sebagai sebuah praktik ideologis dan kekuasaan yang didukung oleh berbagai pengetahuan untuk tujuan tersebut.

Berdasarkan alasan tersebut, tulisan ini membongkar praktik konstruksi wacana estetika, terutama pada era 1900-1945. Fokus perhatian yang utama adalah bagaimanakah wacana estetika romantisme itu terbentuk dan bagaimanakah penyebarannya. Untuk menunjukkan keadaan tersebut, hal utama yang perlu ditunjukkan adalah wacana estetika yang dominan, yang menjadi sebuah landasan untuk mengetahui berbagai wacana estetika yang lain, yang berkembang dan ada pada masa yang sama. Hal ini dimaksudkan untuk memberi berbagai cara atau petunjuk guna mengetahui berbagai penyebaran wacana estetika dan pembentukan wacana estetika yang ada.

Berbicara mengenai wacana yang dihubungkan dengan kuasa dan pengetahuan, Foucault (2012) mengemukan tentang kesatuan wacana, yakni segala sesuatu berhubungan dengan wacana dan tidak ada titik akhirnya. Dengan kata lain, satu wacana dikuatkan atau didukung oleh wacana yang lain. Wacana yang mungkin pertama kali muncul akan dijelaskan atau ditentang dengan wacana yang lain. Sebagai akibatnya, hubungan antar wacana itu dapat dikemukan. Wacana satu dengan yang lain pada dasarnya bisa serupa ataupun beda kehadiran. Mereka merupakan sesuatu yang berhubungan satu dengan yang lain.

Faruk (2012) mengemukan bahwa wacana Foucault itu beranggapan bahwa tiap masyarakat memiliki produksi wacana yang dikontrol, diseleksi, diorganisasi, dan distribusikan melalui berbagai prosedur yang ada. Para prosedur itu mengawasi kuasa-kuasa dan bahaya yang muncul guna mendapatkan penguasaan atas peristiwa yang ada, baik secara kebetulan. Salah satu prosedur yang sering digunakan adalah sistem ekslusi atau pelarangan. Foucault sendiri membagi sistem ekslusi itu diantaranya adalah pelarangan yang saling berinteraksi, saling 
memperkuat, dan melengkapi. Larangan itu diantaranya adalah larangan objektif (tidak semua orang memiliki orotoitas berbicara), larangan konstektual (tidak semua orang boleh bicara mengenai sesuatu dalam konteks san peristiwa tertentu), dan larangan subjektif (tidak semua orang bisa bicara mengenai segala hal). Tentu saja, larangan ini berhubungan dengan kekuasan dan keinginan atau pengetahuan. Bentuk dari hal itu berupa pemisahan dan penolakan, yang bertujuan untuk menunjukkan gagasan tentang yang benar dan salah.

Lembaga kekuasaan yang beragam merupakan sebuah kekuasaan yang melindungi dan menciptakan wacana. Instansi pengatur seperti pemerintah, penerbit, subjek, perantara, pembatas, lembaga, dan lain-lain memiliki tugas yang sama yakni menata hubungan berbagai kekuasaan yang ada dalam berbagai wacana yang diciptakan. Dia bertugas mendistribusikan dengan berdasarkan hubungan hirarkis yang mapan (Foucault, 2008). Berbagai pihak memberi batasan dan pihak lain memberikan aturan atas berbagai produk kultural dan sosial, termasuk karya sastra, dalam wilayah kekuasaannya. Kekuasaan ini memiliki hubungan yang penting sebab mengatur berbagai wacana yang ada di dalamnya. Dia bisa melemahkan, menguatkan, mendistribusikan, dan mengatur berbagai wacana yang ada. Bahkan, hal itu memberikan stimulus atas kemunculan wacana yang baru, baik sepihak atau bertentangan dengan dirinya.

Menurut Foucault (2008), keberadaan wacana satu dengan yang lain tidak terlepas dari kekuasaan. Bahkan, antara satu wacana dengan wacana yang lain meski bertentangan memiliki satu kandungan kuasa yang sama. Selanjutnya, modalitas penyampai dalam wacana ini dapat berasal dari mana saja, seperti siapa yang berbicara, situs-situs institusional, dan posisi subjek yang bertindak (Foucault, 2012). Untuk mengetahui penyebaran wacana dan sekaligus menganalisis wacana yang mendominasi atas suatu objek tertentu, hal yang pertama yang harus diketahui adalah landasan kekuasaan yang berada dan mendominasi wacana tersebut. Tentu saja, subjek memiliki strategi dalam melanggengkan kekuasaan atas keberlangsungan subjek. Dengan berbagai strategi, dia menciptakan sesuatu. Wacana yang diciptakan atas berbagai raelitas itu tidak bersifat tunggal dan terus berlangsung tanpa akhir. Dia menyebar ke segala penjuru yang beraneka ragam.

\section{METODE}

Objek kajian formal dalam penelitian ini adalah wacana estetika romantisme dalam sejarah sastra Indonesia. Objek material berupa sejarah kesastraan Indonesia periode kolonial Belanda (1900-1942). Data penelitian berupa berbagai tulisan tentang sejarah sastra Indonesia, wacana estetika yang berkembang dalam sejarah sastra Indonesia, ide atau gagasan mengenai kesastraan Indonesia, kritik sastra, dan berbagai pernyataan para aktor/pelaku, lembaga, dan ahli sastra mengenai kesastraan Indonesia. Teknik interpretasi data dilakukan berdasarkan tuntutan metode dari teori wacana Foucault. Menurut Faruk (2012) ada beberapa langkah dalam teknik analisis data, yakni prinsip pembalikan, prinsip ketidaksinambungan, prinsip spesifisitas dan prinsip eksterioritas. Beberapa prinsip tersebut dikelompok dalam dua arah analisis, yakni analisis kritis (pelarangan, ekslusi, displin) yang merupakan kontrol atas wacana dan analisis geneologi wacana, yang merupakan penentuan batas-batas wacana tersebut menyebar bersama dengan wacana yang ada.

\section{HASIL DAN PEMBAHASAN Larangan dan Sistem Eksklusi}

Sebagian ahli dan kritikus menyebutkan bahwa sejarah sastra Indonesia dimulai era Balai Pustaka, seperti Pradopo (1995), (Teeuw, 1980), dan lain-lain. Penilaian ini bukan hanya pada persoalan waktu saja, tetapi hal ini berdampak pada cara mengartikan dan menginterpretasikan 
kesastraan dan berbagai fenomena sastra. Kelahiran kesastraan dan cara pandang para ahli sastra pada masa awal sebagian besar dipengaruhi gagasan sastra romantik, seperti pengertian romantik di Eropa beberapa abad sebelumnya. Gagasan sastra atau tradisi romantik ini dapat dilihat pada masa awal kesastraaan Indonesia oleh para ahli sastra. Selain gagasan romantik, gagasan yang lain adalah gagasan yang bersifat formalistik. Baik yang romantik dan formalitasik ini merupakan gagasan yang berasal dari materialisme Barat (Bertrand, 2007).

Contoh dari gagasan romantik ini dapat dibuktikan dari tulisan dan pendapat, seperti Sastrowardoyo (1980). Sementara itu, gagasan yang bersifat formalistik dapat dilihat dari kajian seperti Sulastin Sutrisno (Hikayat Hang Tuah; Analisis Struktur dan Fungsi, 1983). Kedua kritik sastra itu memiliki kecenderungan untuk melepaskan hakikat kesastraan dalam konteks sosial masyarakat. Artinya, presepsi masyarakat terhadap kesastraan dengan pelan dan tersistematis disamakan melalui gagasan romantisme dan formalistik yang materialisme. Sebagai akibatnya, fungsi kesastraan sebagai upaya spritualitas atau konteks lokal menjadi hilang. Pengertian ini dikembangkan dalam melihat kesastraan Indonesia.

Pemerintah kolonial tampaknya merancang atau memberikan sebuah desain terhadap politik kebudayaan atau politik identitas. Kemenangan politik atau gagasan liberalisme di Eropa cukup membawa pengaruh bagi kebijakan kebudayaan (kesastaraan) di tanah jajahan (Burhanudin, 2014). Sebagai contoh adalah usaha standarisasi identitas pribumi atau tanah jajahan, seperti di Eropa. Konstruksi identitas manusia terjajah dan kebudayaan adalah contohnya. Untuk mengendalikan keadaan tersebut, salah satunya, pemerintah kolonial mengadakan kebijakan penyediaan bahan bacaan sebagai bagian dari "politik etis" (Jedamski, 1992). Pembentukan Balai Pustaka, awalnya Commissie voor de Volkslectuur dan menjadi Kantor voor de Volkslectuur, sangat berpengaruh pada standarisi identitas dan cara pandang terhadap kesastraan dan program bahasa Melayu (Maier, 1993).

Selain itu, perkenalan terhadap kajian sastra, yang dilakukan para orientalis, filolog, lembaga sastra (Balai Pustaka), dan penerbitan teks-teks sastra baik terjemahan atau "karya bukan terjemahan", menunjukkan bahwa ada usaha tersembunyi untuk mengkokohkan satu gagasan yang dominan dalam sejarah kebudayaan dan kesastraan, yang mengarah politik "sastra dunia" (Graham, Niblett, \& Deckard, 2012). Hal itu dicontohkan pada kesastraan tradisi Balai Pustaka, yang tidak membicarakan poltik, SARA, dan pelanggaran "moralitas", yang dikenal sebagai Nota Rinkes (Jedamski, 2009). Sementara itu, masa Pujangga Baru, gagasan romantisme menjadi landasan utama dalam kesastaran. Romantisme sendiri dipandang sebagai kekuatan yang membawa nasionalisme keindonesiaan (Faruk, 2002).

Perkenalan-perkenalan tersebut pada dasarnya telah menghilangkan keragaman konsep kesastraan dalam masyarakat etnis atau suku-suku bangsa di Hindia Belanda ketika itu. Hal ini merupakan upaya penyingkiran kesastraan lokal melalui negasi pada gagasan estetika sastra dunia atau kanon milik mereka (Lazarus, 2011). Mereka terjebak pada pola dan berbagai argumen ilmiah mengenai kesastraan. Sastra dianggap sebagai sebuah seni yang menghibur, ekspresi jiwa pengarang, dan bermediumkan bahasa. Selain itu, dia harus mengungkapkan sebuah ekspresi yang membawa pesan moralitas, sebagai sarana pengajaran dan sekaligus hiburan. Namun, konsep kata sastra pun direduksi sedemikian rupa menjadi "alat pengajaran". Sastra dengan demikian serupa dengan tulisan yang indah dan membawa manfaat bagi pembaca. Hal ini dapat dicontohkan dari buku atau tulisan yang mengimplikasikan gagasan romantik dan materialistik dalam memberikan penilaian atas karya sastra atau fenomena kesastraan hingga objek yang lain (Hadzigeorgiou \& Schulz, 2014).

Usaha ini dilanjutkan dengan perkenalan pada karya sastra terjemahan. Pemerintah kolonial Belanda menerbitkan berbagai terjemahan dari sastra Barat. Terjemahan itu dipilih atau diseleksi sedemikian rupa dengan menekankan pada gagasan "sastra romantis" sebab terjemahan memiliki implikasi ideologis dan politis (Bassnett \& Trivedi, 2012). Teks-teks yang 
diterbitkan dalam sastra terjemahan diantaranya adalah cerita petualangan, cerita hero atau kepahlawaan, percintaan, dan detektif. Sebagai contohnya adalah Robinson Crousoe karya Daniel Defo yang mengedepankan gagasan manusia super dan dapat menemukan atau menguasai pulau terpencil. Cerita ini sekaligus menampilkan kemenangan pikiran atau kebudayaan atas alam (Prasojo \& Susanto, 2015). Teks-teks tersebut memberikan pengaruh dalam kesastraan Indonesia pada masa selanjutnya atau masa pembentukan tradisi sastra Balai Pustaka. Hal ini terlihat jelas pada cerita atau kesastraan Jawa yang mengenalkan tradisi sastra perjalanan (Quinn, 1992). Secara umum, tujuan terjemahan tanpa disadari telah membentuk konstruski identitas atau "citra estetika" bagi keberlangsungan sejarah kesastraan Indonesia.

Gagasan mengenai kesastraan yang materialisme ini didukung oleh berbagai kajian atau kritik sastra. Kajian atau kritik sastra merupakan wujud dari paradigma atau sudut pandang dalam mengartikan "sastra". Kajian-kajian pada masa awal yang berkembang ("pembentukan sastra Indonesia modern") adalah kajian romantis dan formalistik. Kajian ini muncul pada masa berikutnya, yakni kritik sastra HB Jassin, Subagio Sastrwardoyo, hingga buku sejarah sastra dari A Teeuw. Namun, pada masa awal ini, kajian estetika seperti struktur pantun, puisi, dan keutamaan pengarang menjadi dasar yang utama. Hal ini dapat dicontohkan melalui berbagai kajian yang telah dilakukan seperti gagasan dari (Alisjabana, 1954), Armijn A. Pane (1933) ("Kesusastraan Baru I; Sifatnja”), S. Pane (1937) ("Jagat besar dan kecil”), dan lain-lain. Larangan dan sistem ekslusi yang lainnya dapat dilihat melalui gagasan yang berkembang pada masa "sesudah kolonialisme Belanda", meski pada hakikatnya, kolonialisme Belanda itu terus berkembang dan mencengkram akal dan pikiran masyarakat "bekas jajahan".

Sistem larangan dan ekslusi ini seakan tidak secara nyata atau eksplisit ditunjukkan untuk membentuk konstruksi estetika sastra Indonesia. Namun, berbagai komentar, tanggapan, dan kajian dari para ahli sastra dan pakar sastra era kolonial mengarah pada hal tersebut. Hal ini diperkuat dengan kajian atau komentar pada masa sesudahnya, seperti pada beberapa tulisan yang telah disebutkan. Fakta ini sekaligus mengokohkan bahwa terdapat kekuasaan dan pengetahuan yang melakukan praktik melalui larangan yang tersembunyi dan ekslusi terhadap sejarah kesastraan Indonesia. Larangan dan ekslusi ini dapat dilihat melalui kekuasaan lembaga kolonial, ahli dan kritikus ("ilmuwan") kolonial, dan juga pengetahuan yang menyertai sebagai pemegang otoritas ilmiah.

Pada masa sesudahnya, fakta tersebut semakin terlihat nyata ketika hal itu dihadapkan pada berbagai penelitian dan kritik sastra yang ada. Sebagai contoh adalah masa Orde Baru. Gagasan mengenai dunia pengarang dan kreativitas menjadi contoh. Hal ini dapat dilihat dari penelitian untuk skripsi, tesis, atau penelitian yang lain di era 1980-an sampai dengan 2000-an. Gagasan psikologi sastra beserta teori yang menyertai dan teori struktural adalah contoh dari upaya pembatasan dan ekslusi dalam memandang atau melihat fenomena kesastaraan.

\section{Displin dan Pembatasan}

Selain melalui larangan yang tersembunyi dan sistem ekslusi, penulisan sejarah sastra Indonesia sebagai bagian dari politik estetika ini ditunjukkan melalui sistem displin dan pembatasan. Sistem displin dan pembatasan ini secara nyata memanfaatkan kekuasaan dan pengetahuan seperti yang terjadi pada larangan dan ekslusi. Berikut ini adalah beberapa contoh dari displin dan pembatasan dalam upaya menyusun sejarah kesastraan Indonesia.

Konsep mengenai bacaan liar merupakan "lahan" yang paling sempurna untuk menunjukkan hal ini. Secara umum, bacaan liar ini diberikan kepada teks-teks sastra yang tidak sejalan dengan teks versi pemerintah kolonial. Melalui konsep-konsep estetika tertentu, seperti penggunaan bahasa dan isi cerita, teks-teks di luar kanon atau tradisi Balai Pustaka (kolonial) dinyatakan sebagai teks atau bacaan terlarang dan liar (Sulton, 2015). Dalam praktiknya ini, pemerintah kolonial pada dasarnya melakukan pembatasan terhadap karya sastra yang dianggap 
sebagai sastra. Selain itu, dia sekaligus juga melakukan upaya pendisplinan terhadap pandangan atau kajian sastra atau konsep estetika, yakni bahwa karya sastra yang demikian dilarang secara tegas dan dianggap sebagai sastra. Dia (lembaga kolonial) mengeluarkan sebuah "manifesto sastra" yang dipandang dan layak untuk dianggap sastra. Sebagai akibatnya, karya sastra atau sastra yang dipandang sebagai bacaan liar itu tidak akan pernah masuk kriteria estetika. Selain itu, melalui serangkaian pengetahuan romantisme dan perangkat kolonial, dia akan tersingkirkan seperti konsep kritik sosial dalam sastra di Era Orde Baru (Sudewa, 2016).

Salah satu dari perangkat dan pengetahuan yang digunakan oleh kekuasaan kolonial adalah konsep bacaan untuk rakyat dan moralitas. Bacaan untuk rakyat (masyarakat terjajah) adalah bacaan yang memiliki gagasan mendidik dan tidak membuat suatu kerusuhan. Bacaan itu adalah bacaan yang mengedepankan moralitas. Bacaan yang demikian ini telah diungkapkan dalam aturan Balai Pustaka seperti yang dikenal dengan sebutan Nota Rinkes. Dalam praktiknya, kesastraan yang membicarakan kekacauan (pemberontakan), sebagai contohnya Hikayat Siti Mariah (1907-1912) oleh Hadji Moekti ataupun kasus Salah Asoehan, hingga cerita pernyaiaan tidak dipandang sebagai kesastraan, tetapi bacaan liar dan mempertontonkan kecabulan atau kekacauan. Hal serupa juga berlaku bagi kesastraan yang mengedepankan realitas masyarakat tentang pelacuran dan pernyaian, yang dilakukan oleh para pejabat kolonial ataupun orang Belanda sendiri. Sastra yang demikian itu dipandang sebagai bacaan murahan, cabul ataupun bacaan tidak bermoral. Sebagai contohnya adalah novel Kota Medan Penoeh dengen impian atawa Njai jang bertaboer Mas (1928), Boekoe tjerita resianja goela-goela (1912), atau kasus yang sensasional seperti Nona Fientje de Feniks atawa djadi korban tjemboeroean (1915), dan lain-lain. Fakta serupa akan muncul dalam kajian sastra yang ditulis oleh kelompok kiri dalam sejarah sastra Indonesia (Artika, 2016).

Gagasan serupa juga dilakukan dalam kesastraan yang memiliki spirit agama. Kesastraan yang demikian itu telah disingkirkan sebaik-baiknya, melalui kajian terhadap kesastraan Melayu klasik. Mereka melakukan penelitian atas teks-teks keagamaan dan politik sebagai karya yang disebut karya sastra, seperti kemunculan sastra kitab, sastra undang-undang, sejarah, pelipur lara, dan lain-lain. Kajian itu membuat kategori tertentu dengan berbagai kajian formula untuk memasukkan teks-teks keagamaan dan politis sebagai kesastraan. Artinya, kesastraan tidak boleh membicarakan agama sebab hal itu bukan bagian dari gagasan formula sastra dan moralitas. Sebab, agama berhubungan dengan Tuhan dan bersifat pribadi dan bukan konsumsi publik. Sesungguhnya, fakta ini untuk menghindari gagasan "pemberontakan" dari kalangan Islam atas kekuasaan kolonial (Effendi, 2012), (Aisyah, 2015). Sebagai akibatnya, kesastraan yang demikian tersingkirkan dan dipandang bukan sastra.

Berhubungan dengan bacaan liar, pemerintah kolonial juga melakukan berbagai upaya seperti penelitian dan pelembagaan kesastaraan. Sebab, kesastraan diyakini sebagai kekuatan diskrusif terakhir yang dapat menimbulkan perlawanan dan sekaligus berpotensi sebagai ancaman. Maka, pengaturan kesastaraan atau bacaan ini diserahkan oleh lembaga Balai Pustaka, yang awalnya Komisi Bacaan Rakyat. Melalui lembaga ini, pemerintah kolonial melakukan displin dan pembatasan atas berbagai wacana estetika yang berkembang. Displin dan pembatasan itu dilakukan oleh lembaga ini untuk memberikan tandingan atas berbagai wacana estetika yang berkembang pada era itu, seperti kesastraan Islam, lokalitas, ataupun wacana estetika bacaan liar (perlawanan), yang sengaja dibentuk oleh wacana estetika romantisme versi lembaga Balai Pustaka.

Wacana estetika romantisme yang dikukuhkan lembaga kolonial melalui pendisplinan dan pembatasan ini tidak hanya pada wacana estetika saja, tetapi individu dan lembaga tertentu yang dipandang sebagai bagian dari wacana estetika yang dikekang. Hal ini dapat dicontohkan melalui penahanan para penulis sastra dan penghentian terbitan atau surat kabar yang dipandang sebagai penyebar gagasan anti wacana estetika milik lembaga kolonial seperti tulisan mengenai 
perlawanan terhadap kekuasaan pemerintah Belanda (Sulton, 2015). Namun, ada fakta yang menarik lainnya bahwa wacana anti pada wacana estetika kolonial ini memanfaatkan estetika kolonial untuk melawan kolonial. Hal ini menunjukkan semacam mimikri, tetapi pada hakikatnya bersifat resistensi. Salah Asoehan adalah contoh yang lolos sensor kolonial. Mimikri itu hanya terletak pada bentuk formalnya, tetapi bukan pada konstruksi identitasnya (Hafid, 2018). Contoh dari penahanan atas pengarang adalah kasus pada Marcodikromo ataupun Tirto Adhi Soerja atau larangan terbit bagi Medan Prijaji dan lain-lain. Gagasan yang demikian merupakan sebuah upaya pendisplinan dan pembatasan wacana yang lain dan sekaligus menyebarkan wacana estetika yang dibangunnya. Hal ini sangat berpengaruh pada penulisan sejarah sastra pada masa berikutnya.

Selain lembaga, tradisi pendisplinan dan pemabatasan ini juga dilakukan oleh para pakar sastra atau pelaku sastra yang masuk dalam kelompok wacana estetika kolonial. Hal ini terlihat pada masa berikutnya. Ungkapan dari para pengarang Pujangga Baru adalah bukti dari hal itu. Era Pujangga Baru memunculkan gagasan romantisme dan era 1945 menghasilkan gagasan individualisme. Fakta ini dikuatkan dengan persoalan Polemik Kebudayaan hingga Surat Kepercayaan Gelangang (Susanto, 2018). Polemik Kebudayaan (Mihardja, 1986) tersebut merupakan pertunjukkan tentang cara wacana estetika satu dengan yang lain saling berebut dan saling menonjolkan kekuatan atau eksistensi.

Sebagai contoh dari pernyataan tersebut adalah gagasan antara Sanusi Pane dan Sutan Takdir ataupun Supomo (Mihardja, 1986). Masing-masing pihak menunjukkan konsep atau cara pandang yang berbeda dalam memandang identitas dan kebudayaan Indonesia. Mereka terpolarisasi antara perdebatan lokalitas, Timur, Islam, Barat, dan gabungan diantaranya. Wacana estetika yang berkembang pada masa itu dapat diambil dari gagasan yang dicetuskan oleh para intelektual atau aktor dalam Polemik Kebudayaan tersebut. Pada dasarnya, pernyataan-pernyataan dan gagasan yang diungkapkan oleh para aktor Polemik Kebudayaan itu tanpa disadari membawa wacana-wacana estetika yang beragama. Mereka berebut dan hidup dalam wilayah masing-masing.

Selain pada aktor kebudayaan, kajian ilmu sastra atau kritik sastra juga mengedepankan gagasan tersebut. Bahkan, para pelaku kesastraan juga ikut mengilhami gagasan tersebut. Sebagai contoh adalah Angkatan Pujangga Baru, yang terilhami oleh gerakan romantisme tahun 1880-an di Belanda. Para sastrawan Pujangga Baru juga mengedepankan gagasan romantisme dalam penciptaan karya sastra. Tradisi yang demikian ini dilanjutkan oleh gagasan individualisme semasa angkatan Chairil Anwar (Sastrowardoyo, 1980). Para ktrikus sastra pada era selanjutnya mengunakan gagasan kritik sastra humanisme seperti H.B. Jassin, (Pudjangga Baru Prosa dan Puisi, 1961 atau Tifa Penyair dan Daerahnya, 1952), A Teuuw (Pokok dan Tokoh Kesusastraan Indonesia Jilid I dan II, 1952, 1958), Junus Amir Hamzah (Hamka Sebagai Pengarang Roman, 1963), M.S. Hutagalung (Pramoedya Ananta Toer dan Karya Seninya, 1963), dan lain-lain.

Gagasan tentang konstruksi tradisi romantisme ini terlihat pada peluncuran majalah Pujangga Baru, "Madjalah Kesoesasteraan dan Bahasa, Poedjangga Baroe" oleh Arjine Pane, Amir Hamzah, dan Sutan Takdir Alisjahbana (1933) dan beberapa gagasan yang lainnya seperti "Kesoesateraan Baroe" (A. Pane, 1933). Pandangan dari pelaku sastra ini dapat menjadi contoh dari dominasi kekuataan wacana estetika romantisme dalam membangun konsep kesastraan Indonesia atau sejarah sastra Indonesia. Selain pernyataan dari para ahli dan pelaku sastra, gagasan yang demikian ini juga diperkuat dengan pandangan yang berasal karya sastra yang dihasilkan. Sebagai contoh adalah karya sastra Balai Pustaka seperti yang dikemukan oleh (Faruk, 2002), bahwa gagasan romantisme menjadi bagian dari ideologi dan praktik kolonial dan sekaligus erlawanan kolonial melalui gagasan cerita yang disembunyikan. 


\section{Genealogis Wacana}

Berdasarkan sistem larangan, displin, dan pembatasan, wacana estetika dalam penulisan sejarah sastra Indonesia secara tidak langsung telah menyingkirkan berbagai wacana estetika yang lain. Wacana tersebut seharusnya diakomodasi sebagai bagian dari sejarah sastra Indonesia. Akan tetapi, wacana sastra tradisi Balai Pustaka atau romantik dan materialisme menjadi wacana yang mendominasi. Peran wacana estetika yang lain seakan berdiri sendiri dan terlepas dari wacana estetika yang dominan. Namun, pada hakikatnya, hal itu tidaklah demikian. Sebaliknya, kehadiran berbagai wacana estetika yang berbeda dengan yang dominan itu dapat memiliki berbagai kemungkinan, seperti sebagai cara bertahan, wacana tandingan, atau komentar atas wacana yang dominan. Bahkan, hal itu sama sekali tidak berhubungan, meski hal itu sangat kecil kemungkinannya. Berikut ini adalah berbagai wacana estetika yang berkembang secara bersamaan dengan wacana estetika romantisme pada masa kolonial. Wacana estetika tersebut diantaranya adalah wacana sastra perlawanan, wacana Islam (pendidikan pesantren), wacana sastra peranakan Tionghoa, dan tradisi lokalitas.

Wacana estetika sastra perlawanan, wacana estetika sastra perlawanan ini pada dasarnya muncul setelah kemerdekaan Indonesia, meski pada dasarnya sastra ini sudah ada sejak era kolonial. Sastra perlawanan ini merupakan sebutan dari bacaan liar atau sastra yang melawan kuasa kolonial atau berbeda dengan sastra versi romantisme kolonial. Sastra ini hadir dan sengaja disingkirkan dalam penulisan sejarah sastra Indonesia "modern". Penyebutan estetika perlawanan ini juga dihubungkan dengan sastra Marxis pada masa Orde Baru. Sastra Marxis sendiri adalah sastra yang memang "dilarang" oleh dominasi estetika era Orde Baru.

Kemunculan wacana estetika sastra perlawanan yang identik dengan bacaan liar pada masa kolonial tampaknya juga diteruskan pada masa sesudahnya, misalnya era Orde Baru. Penyebutan sastra perlawanan juga mengandung implikasi bila dihubungkan wacana estetika Marxisme. Hal ini juga berhubungan dengan era sebelumnya yakni era 1950-1965. Era itu, Partai Komunis Indonesia (PKI) dipandang sebagai pihak yang bertanggung jawab pada peristiwa "kudeta" 1965. Pelekatan wacana sastra perlawanan sering dihubungkan untuk melawan kekuasaan yang sah. Hal serupa dilakukan juga oleh pemerintah kolonial yang mengedepankan sastra liar atau bacaan liar sebagai bacaan subversif. Secara umum, wacana sastra perlawanan juga hadir dan dibangun oleh kelompoknya sendiri sebagai wujud resistensi atas kekuasan yang ada. Dengan penyebutan sastra perlawanan oleh pihak yang memiliki kuasa dan membuat wacana itu sebagai yang liar, yang dihindarkan, dan yang diberantas, pemilik dan pelaku wacana sastra perlawanan justru mapan dengan sebutan itu dan dijadikan sebagai propaganda atas perlawanan yang dilakukan. Jadi, kehadiran wacana sastra perlawanan pada masa kolonial dipandang sebagai usaha melawan kekuasaan kolonial melalui sebutan bacaan liar. Namun, pada masa Orde Lama, wacana estetika sastra perlawanan ini juga dianggap lawan dari estetika romantis yang menyetujui kekuasaan pemerintah ketika itu. Namun, hal itu perlu penyelidikan lebih lanjut untuk mengetahui kekuatan dan pemiliki wacana itu atau siapa yang dimanfaatkan, untuk apa dihadirkan dan apa tujuan kehadirannya. Hal itu bisa dimungkinkan bahwa wacana tersebut dibentuk dan dihadirkan oleh lawan mereka sendiri.

Wacana estetika Islam, wacana estetika religi ini memang sudah hadir sebelum wacana estetika sastra romantisme ini muncul atau dikenalkan oleh kolonialisme Belanda. Hal ini dapat dicontohkan dalam kekayaan kesastraan Melayu klasik. Kehadiran satra Melayu klasik hampir seluruhnya adalah wacana sastra Islam, yakni sebagai bentuk pengagungan pada Allah SWT dan menjadi alat untuk mendekatkan manusia dengan Tuhan. Sebagai contohnya adalah "proses islamisasi" karya sastra Hindhu menjadi Islam, misal Hikayat Sri Rama dan lain-lain. Karya sastra seperti kitab ajaran agama, tasawuf, dan hukum agama atau cerita pelipur lara menjadi bagian dalam bingkai kesastaran estetika Islami. Dalam era kolonial, wacana ini hadir dalam dunianya sendiri, seperti dalam pendukung atau kelompok-kelompok tertentu. Contoh dari itu 
adalah di dunia santri, pedesan, dan pesantren. Mereka menulis kitab sejarah, kitab ajaran agama, hingga pujian-pujian terhadap tokoh Islam dan kecintaan pada Nabi Muhammad ataupun istilah sastra Islam Nusantara (Rohmana, 2016), konsep pendidikan Islam dan kesastraan (Sunhaji, 2015) atau sastra pesantren (Zuriyati, 2011), (Muniroch, 2014). Mereka hadir "di pelosok" dan jauh dari wacana dominan sastra nasional atau sastra kolonial pada masanya.

Usaha penyingkiran wacana sastra Islam-i ini berhubungan dengan kekuasaan kolonial dan Islam atau misi penyebaran agama Kristen dan Katolik oleh pemerintah kolonial. Mereka takut terhadap peran kyai dan dunia Islam. Pemerintah kolonial melakukan serangkaian kebijakan terhadap dunia Islam dan karya sastra. Mereka meneliti karya sastra Islam klasik di tanah jajahan hanya sebatas pada usaha manusia untuk mendekatkan diri pada Tuhan atau hubungan manusia dengan Tuhan. Mereka menghindari dan membuat sebuah pola bahwa kesastraan Islam klasik di tanah jajahan tidak berbicara politik, kekuasaan, dan hubungan dengan penguasa. Mereka hanya berbicara masalah hubungan manusia untuk bisa beribadah dengan Tuhan-nya. Di era kolonial, wacana estetika Islam ini muncul melalui Polemik Kebudayaan tentang identitas keindonesiaan melalui gagasan pendidikan berbasis pesantren.

Di era selanjutnya, wacana estetika Islam ini melakukan sebuah politik praktis, misalnya tahun 1950-1965. Dia hadir di tengah wacana estetika sastra romantis dan materailistik melalui politik praktis. Mereka berafiliasi dengan partai-partai yang berbasis agama Islam. Mereka membentuk Lembaga Seniman Budayawan Muslimin Indonesia (Lesbumi), Himpunan Seni Budaya Islam (HSBI), Lembaga Kebudayaan dan Seni Islam (Leksi), hingga Lembaga Kebudayaan Syarikat Muslimin Indonesia (Laksmi) dan Majelis Seniman dan budayawan Islam) (Susanto, 2018). Sementara itu, kelompok agama non-Islam juga muncul kesastraan yang serupa. Di Era Orde baru, estetika Islam mulai redup dalam pentas sastra yang dominan. Estetika materialisme dan romantisme tetap menjadi yang dominan. Estetika religi atau Islam dihilangkan atau didisplinkan oleh kekuasaan Orde Baru melalui sebuah pernyataan bahwa "Islam yang politis berarti termasuk kelompok kanan" yang anti kekuasaan yang sah. Pola ini merupakan pola yang sama di zaman kolonial Belanda. Lalu, kesastraan estetika religi atau Islam ini beralih menjadi berbagai wujud seperti sastra sufi, sastra tasawuf, sastra trasendental, sastra religiositas, dan lain-lain. Hal ini pada intinya mengatur hubungan manusia dengan Tuhan dan bukan memasalahkan kekuasaan dan keduniawian.

Selain itu, dalam konstelasi wacana sastra romantisme era kolonial, wacana estetika lokal atau sastra lokal juga mengalami hal serupa seperti estetika yang lain. Namun, estetika lokal ini hadir hanya sebagai pelengkap dalam konstelasi wacana estetika romantisme. Bahkan, ada sejumlah usaha yang terstruktur dan sistematis untuk menjadikan estetika lokal serupa atau sama seperti estetika romantisme atau materialisme. Sebagai contoh adalah sastra rakyat, misal pantun. Pantun dikaji struktur atau formulanya, seperti isi dan sampiran. Hal serupa juga terjadi terhadap teks-teks yang lain, misal babad atau kronik mitologis yang dikaji dengan sudut padang struktural atau kesamaan-kesamaan motif cerita. Hal itu pada dasarnya untuk mengokohkan wacana estetika romantis. Di era selanjutnya, wacana estetika lokal ini masih serupa posisinya. Hal ini serupa dengan kesastraan daerah yang hanya dikaji dan dikembangkan sebagai wujud pelestarian nilai-nilai tradisi. Lembaga pengkajian nilai-nilai tradisi lokal atau tradisional adalah salah satu contohnya. Di era tahun 1990-an, ada sebuah perlawanan atas wacana dominan, misalnya kemunculan sastra perdalamaan atau era tahun 1990-an (Derks, 2004), sastra kontekstual, dan sastra yang berbasis lokalitas.

Wacana sastra etnik juga mengalami hal yang serupa, yakni disingkirkan oleh estetika yang dominan, yakni romantisme. Sebagai contoh dari keadaan itu adalah sastra peranakan Tionghoa di era kolonial. Sastra ini dengan estetika perjuangan dan recinanisasi (kembali pada ajaran Khong Hucu) yang berisi perlawanan terhadap konstruksi kolonial (Susanto, 2017) 
dibuat menjadi "sang lain" dalam sejarah estetika sastra Indonesia. Dia sama sekali tidak hadir dalam buku-buku sejarah sastra Indonesia pada masa Orde Baru ataupun era kolonial. Bahkan, cenderung dianggap sastra picisan dan murahan seperti pada Roman Pergaoelan atau Roman Picisan di Bukit Tinggi dan sekitarnya. Sebagaimana hasilnya, keadaan yang demikian ini hakikatnya hanya untuk mengunggulkan dan menampilkan sebuah wacana dominan dalam sejarah kesastaraan Indonesia, yakni estetika romantisme Eropa.

\section{SIMPULAN}

Formasi wacana atau geneaologi (sejarah) wacana estetika romantisme dalam penulisan sejarah sastra Indonesia menunjukkan bahwa kehadiran romantisme membawa implikasi yang bersifat politis, yakni sebagai sebuah rangkaian untuk mengkokohkan kuasa dan pengetahuan dunia Barat melalui praktik kolonial. Hal ini digunakan untuk mengkokohkan kekuasaan kolonial yang beroperasi dengan cara membentuk identitas masyarakat terjajah melalui dunia kesastaraan. Dengan memperkenalkan wacana estetika romantisme dan materialisme Barat, penjajahan atas pikiran dan jiwa manusia dapat dilakukan melalui dunia kesastraan, yang dipandang menjadi kekuatan diskrusif terakhir dalam masyarakat terjajah.

Keadaan yang demikian ini dilanjutkan pada masa berikutnya, yakni Era Orde Lama. Kemenangan wacana estetika romantisme dan materialisme di era Orde Baru dipicu pada kegagalaan politisasi kebudayaan pada masa Orde Lama. Hal ini menyebabkan wacana estetika selain wacana estetika materialisme tersingkirkan. Mereka baik pada masa era kolonial ataupun masa Orde Baru mengalami pesamaan dan keberulangan nasib dan posisi. Dominasi wacana tertentu, romantisme atau materialisme, dikokohkan untuk mendukung sebuah kekuasaan melalui serangkaian praktik ilmiah, misal penelitian ilmiah, tanggapan para ahli kesastaraan, dan lain-lain. Kehadiran wacana estetika seperti wacana Islam, lokalitas, atau yang lain hanya sebatas dalam dunianya sendiri dan tersingkirkan.

\section{DAFTAR PUSTAKA}

Aisyah, S. (2015). Dinamika Umat Islam Indonesia pada Masa Kolonial Belanda (Tinjauan Historis). Rihlah Jurnal Sejarah dan Kebudayaan, 2(01), 120-127.

Alisjabana, S. T. (1954). Menudju Masjarakat dan Kebudjaan Baru. Polemik Kebudjaan, cetakan ketiga, Djakarta: Perpustakaan Perguruan Kementrian PP dan K.

Artika, I. W. (2016). Lima Cerpen Propaganda Lekra (1950-1965). Aksara, 28(2), 129-142.

Bassnett, S., \& Trivedi, H. (2012). Postcolonial Translation: Theory and Practice: Routledge.

Bertrand, R. (2007). Sejarah Filsafat Barat: Kaitannya dengan Kondisi Sosio-Politik Zaman Kuno Hingga Sekarang. Yogyakarta: Pustaka Pelajar.

Burhanudin, J. (2014). The Dutch Colonial Policy on Islam: Reading the Intellectual Journey of Snouck Hurgronje. Al-Jami'ah: Journal of Islamic Studies, 52(1), 25-58.

Derks, W. (2004). Sastra Perdalaman: Pusat-Pusat Sastra Lokal dan Regional di Indonesia. In K. F. d. T. Day (Ed.), Sastra Indonesia Modern Kritik Pascakolonial. Jakarta: Yayasan Obor Indonesia.

Effendi, E. (2012). Politik Kolonial Belanda terhadap Islam di Indonesia dalam Perspesktif Sejarah (Studi pemikiran Snouck Hurgronye). Jurnal Tapis, 8(1), 91-112.

Faruk. (2002). Novel-Novel Indonesia Tradisi Balai Pustaka 1920-1942. Yogyakarta: Gama Media.

Faruk. (2012). Metode Penelitian Sastra. Yogyakarta: Pustaka Pelajar.

Foucault, M. (2008). La Volonte de Savoir: Ingin Tahu Sejarah Seksualitas: Yayasan Obor Indonesia.

Foucault, M. (2012). Arkeologi Pengetahuan, terj. Moechtar Zoelmi. Yogyakarta: Qalam. 
Graham, J., Niblett, M., \& Deckard, S. (2012). Postcolonial Studies and World Literature. Journal of Postcolonial Writing, 48(5), 465-471.

Hadzigeorgiou, Y., \& Schulz, R. (2014). Romanticism and Romantic Science: Their Contribution to Science Education. Science \& Education, 23(10), 1963-2006.

Hafid, A. (2018). Diskriminasi Bangsa Belanda dalam Novel Salah Asuhan Karya Abdoel Moeis (Kajian Postkolonial). Kembara, 3(2).

Jedamski, D. (1992). Balai Pustaka: A Colonial Wolf in Sheep's Clothing. Archipel, 44(1), 2346.

Jedamski, D. (2009). Kebijakan Kolonial di Hindia Belanda. In H. Chambert-Loir (Ed.), Sadur Sejarah Terjemahan di Indonesia dan Malaysia. Jakarta: Kepustakaan Populer Gramedia.

Jones, T. (2013). Culture, Power, and Authoritarianism in the Indonesian State: Cultural Policy Across the Twentieth Century to the Reform Era: Brill.

Lazarus, N. (2011). Cosmopolitanism and the Specificity of the Local in World Literature. The Journal of Commonwealth Literature, 46(1), 119-137.

Maier, H. (1993). Beware and Reflect, Remember and Recollect: Tjerita Njai Soemirah and the Emergence of Chinese-Malay Literature in the Indies. Bijdragen tot de Taal-, Land-en Volkenkunde(2de Afl), 274-297.

Mihardja, A. K. (1986). Polemik Kebudayaan. Jakarta: Pustaka Jaya.

Muniroch, S. (2014). Pesantren Literature in Indonesian Literature Constellation. LiNGUA: Jurnal Ilmu Bahasa dan Sastra, 9(2), 155-166.

Pane, A. (1933). Kesusastraan Baru I Sifatnja Poedjangga Baroe I. Jakarta: Pustaka Jaya.

Pane, S. (1937). Jagat Besar dan Kecil Poedjangga Baroe. Jakarta: Pustaka Jaya.

Pradopo, R. D. (1995). Beberapa Teori Sastra, Metode Kritik, dan Penerapannya: Pustaka Pelajar.

Prasojo, A., \& Susanto, D. (2015). Konstruksi Identitas dalam Sastra Terjemahan Eropa Era 1900-1930 dan Reaksinya dalam Sastra Indonesia. Humaniora, Jurnal Budaya, Sastra, dan Bahasa, 27(3), 283-292.

Quinn, G. (1992). Novel Berbahasa Jawa. Leiden: KTILV Press.

Rohmana, J. A. (2016). Sastra Islam Nusantara AKADEMIKA: Jurnal Pemikiran Islam, 21(1), $1-18$.

Salmon, C. (1981). Literature in Malay by the Chinese of Indonesia: a Provisional Annotated Bibliography: Editions de la Maison des Sciences de l'Homme.

Salmon, C. (1994). Aux Origines du Roman Malais Moderne: Tjhit Liap Seng ou les «Pléiades» de Lie Kim Hok (1886-87). Archipel, 48(1), 125-156.

Sarwoto, P. (2018). The Construction of Modernity in Pre-independent Indonesia and its Ensuing Manifestation in Critical Discourse and Literary Theory. Kritika Kultura(30/31), 276-289.

Sastrowardoyo, S. (1980). Sosok Pribadi dalam Sajak: Pustaka Jaya.

Sudewa, I. K. (2016). Social Criticism in Indonesian Literary Works during the New Order Era. Humaniora, 28(2), 185-197.

Sulton, A. (2015). Sastra "Bacaan Liar" Harapan Menuju Kemerdekaan. Jurnal Pendidikan Bahasa dan Sastra, 15(2), 213-227.

Sunhaji. (2015). Sastra dalam Tradisi Pendidikan Islam. Jurnal Kebudayaan Islam, 13(1), 4758.

Susanto, D. (2017). Chinese Society as Depicted in Early Twentieth Century Chinese-Malay Literature. Wacana, 18(1), 256-265.

Susanto, D. (2018). Lekra, Lesbumi, Manifes Kebudayaan; Sejarah Sastra Indonesia Periode 1950-1965. Yogyakarta: CAPS. 
Sykorsky, W. (1980). Some Additional Remarks on the Antecedents of Modern Indonesian Literature. Bijdragen tot de Taal-, Land-en Volkenkunde(4de Afl), 498-516.

Teeuw, A. (1980). Sastra Indonesia Modern I. Ende: Nusa Indah.

Zuriyati, Z. (2011). Sastra Islami Kontemporer Najîb al-Kilânî dalam Memahami Manusia. ISLAMICA: Jurnal Studi Keislaman, 5(2), 326-338. 